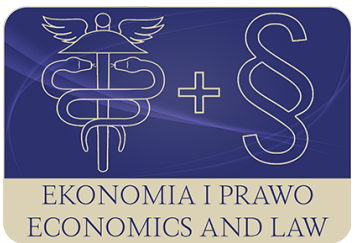

EKONOMIA I PRAWO. ECONOMICS AND LAW

Volume 19, Issue 3, September 2020

p-ISSN 1898-2255, e-ISSN 2392-1625

www.economicsandlaw.pl

ORIGINAL ARTICLE

received 20.10.2019; revised 27.01.2020; accepted 30.09.2020

Citation: Dziadkiewicz, M., \& Cichowski, P. (2020). Real estate management against state policy regarding the development of the fiber optic network. Ekonomia i Prawo. Economics and Law, 19(3): 467-478. doi:10.12775/EiP.2020.031.

\title{
Real estate management against state policy regarding the development of the fiber optic network
}

\author{
MICHAE DZIADKIEWICZ \\ corresponding author \\ Czestochowa University of Technology, Faculty of Management, Department of Logistics \\ and International Management, ul. Armii Krajowej 19b, 42-200 Czestochowa, Poland \\ $\square$ michaldziadkiewicz@gmail.com \\ (D) orcid.org/0000-0001-5450-1669

\section{PAWEE CICHOWSKI} \\ Czestochowa University of Technology, Faculty of Management, Department of Logistics \\ and International Management, Poland \\ $\square$ pawel.piotr.cichowski@gmail.com \\ iD orcid.org/0000-0002-1397-7895
}

\begin{abstract}
Motivation: Contemporary social and economic development is undoubtedly based on access to various types of information. This access is conditioned by the existence and availability of a proper telecommunications infrastructure. In order to provide adequate infrastructure, it is necessary to have proper legal regulations on this subject matter. According to the authors, the issue of providing access to the real estate, and in particular the obligations resulting from it, deserves a special discussion.

Aim: The purpose of this article is to discuss the obligations that property managers have in the field of providing the property to telecommunications undertakings in order to provide telecommunications network. In addition, the purpose of the article is also to draw attention to the specific administrative procedure that may be initiated in the event of failure to fulfill these obligations by the administrators.

Results: Based on the analysis of legal regulations and literature, the responsibilities of property managers, as well as administrative proceedings conducted by the President of UKE were discussed. Attention was also paid to a number of differences that occur
\end{abstract}


in this procedure in relation to the general administrative procedure, including primarily the appeal procedure against the decision issued in the case. Moreover, the article presents statistical data on the number of initiated proceedings and decisions issued by the President of UKE. Summary of the article are conclusions regarding the impact of the fiber network development on property management.

Keywords: telecommunication; fiber; administrative procedural law; civil procedural law JEL: K15; K40; M10; L96

\section{Introduction}

Contemporary social and economic development is undoubtedly based on access to various types of information. This access determines the existence of an appropriate telecommunications infrastructure as well as quick and easy access of the public to services provided through its use. Telecommunications networks are also important in this respect. Their possibilities determine where, how and how quickly specific information will reach the person searching for it. In addition, one can not overlook the fact that telecommunication networks are often used by the public for communication and entertainment (Windekilde \& Ładny, 2011).

The doctrine emphasizes that creating appropriate conditions of competition for telecommunications operators has a positive impact on the development of services provided through the use of telecommunications infrastructure. This undoubtedly affects the scope of these services and their quality (Babis, 2011).

Bearing in mind the above, the legislator aims at introducing appropriate legal regulations, whose purpose is to improve the quality and development in the field of modern telecommunication services. One of the examples of this type of regulation is the Act on supporting the development of telecommunications services and networks (2010). In this act, the legislator specified, among others, forms and principles of supporting telecommunications investments, as well as related rights and obligations of investors, owners, perpetual users of the real estate, persons entitled to a cooperative right to the premises, property managers and tenants.

Therefore, the regulation of the abovementioned act exerts a significant influence on the activity of real estate managers and deserves a special elaboration. The failure of the administrators to perform their duties imposed on them under this Act may lead to the initiation of a special administrative procedure. Its purpose will be the imperious resolution of the administrative case regarding the provision of access to the property to the telecom operator.

\section{Methods}

In order to present and discuss the obligations of the property manager in the scope of ensuring access to the real estate and the procedure that may be initiated in the event of failure to perform this obligation, a thorough analysis 
of the relevant legal regulations and literature devoted to the subject matter has been carried out. What is more, in order to present the number of proceedings conducted by the President of UKE based on the analyzed legal regulation, this authority was asked to provide relevant information. The obtained data was illustrated in charts.

\section{The obligation to provide access to the property}

According to Art. 30(1) of the Act on supporting the development of telecommunications services and networks (2010), the property owner, perpetual user or property manager, who is not a telecommunications undertaking, is obliged to provide the telecommunications company with the access to the real estate, including the building and the contact point, particularly consisting in:

1. ensuringthe possibility of using the existing telecommunications connection or the existing telecommunications installation of the building, if duplication of such infrastructure is economically unprofitable or technically impossible;

2. enabling the telecommunications connection to be brought to the point of contact;

3. enabling the telecommunications installation of the building to be made if:

a. there is no telecommunications installation of the building adapted to provide broadband Internet access services with a bandwidth of at least $30 \mathrm{Mb} / \mathrm{s}$ or

b. the existing telecommunications installation of the building adapted to provide broadband Internet access services with a bandwidth of at least 30 $\mathrm{Mb} / \mathrm{s}$ is not available or does not correspond to the needs of the telecommunications undertaking;

4. enabling the use of the contact point;

5. enabling reconstruction of the telecommunications connection or execution of the telecommunications installation of the building, which have been liquidated, destroyed, damaged or which require modernization or reconstruction;

in order to provide telecommunications in this building.

The legislator also stipulated that the condition referred to in point 3(b) of Art. 30(1), is regarded as fulfilled particularly when the owner of the telecommunications installation of the building does not undertake negotiations with the telecommunications undertaking regarding access to this installation.

What is also important, the obligation to provide access to the property is independent of whether the building has already been completed and whether its use has been started, even if a different telecommunications installation existed or was done in the building.

In literature it is pointed out that the quoted regulation is the key basis enabling the telecommunications company to reach the end-user with the telecommunications network. However, it is this stage that the construction of the telecommunications networks using cable technologies meets the greatest difficulties (Knopkiewicz, 2013). Undoubtedly, this is due to the fear of prop- 
erty managers, owners and perpetual users as to possible damage that may arise in buildings due to the construction of the installation. Moreover, it can be mentioned that the President of the Office of Electronic Communications, in relation to the quoted Act, stated that 'this regulation removes barriers to investments in ICT infrastructure, which considerably accelerates their conduct' (UKE, 2013, p. 2).

In the context of the above, regardless of the benefits that flow from the development of telecommunications networks, there is no doubt that the envisaged legal regulation imposes on property managers a series of obligations which they are forced to reconcile with the will of the owners of these properties. This will might be in contradiction to the intention of the legislator, for example due to the fact that a different operator was previously entrusted with the implementation of the connection to the real estate and optical fiber installation in the building.

In this place, one cannot also neglect the fact that the aforementioned access, as a rule, is provided free of charge. The only exception are the costs related to the provision of the property in order to use the existing telecommunications connection or the existing telecommunications installation of the building or implementing a telecommunications connection to the building or making a telecommunications installation of the building, including the restoration of the original state, as well as the costs of maintaining a shared telecommunications connection, telecommunications installation of the building or the whole or part of the telecommunications cable. For example, the costs related to the consumption of electricity and the rental of space should be pointed out here, the costs which were previously explicitly indicated in the Act as incumbent on the telecommunications company.

The obligation imposed on the property manager is fulfilled by concluding an agreement with a telecommunications undertaking. The deadline for its conclusion is 30 days from the date when the entrepreneur applies to the administrator with an appropriate application. The conclusion of the contract itself should be preceded by negotiations in which the parties reach an agreement on its provisions. It is justified that the contract defines essential conditions relating to the provision of the property and the implementation of the connection and installation, including in particular the ones relating to the preparation of the executive design of the installation, and primarily the date of doing the installation. Moreover, it is also reasonable to specify in the contract the obligations of the telecommunications company related to the performance of inspections of the installation and the removal of potential failures. The agreement should also provide for securing possible claims of the administrator, which might arise as a result of irregularities in the performance of the contract by a telecommunications undertaking (e.g. deposit).

On the other hand, bearing in mind Art. 24(1) and (2) in connection with Art. 30(5) of the Act on supporting the development of telecommunications services and networks (2010), it should be mentioned that the party to the agreement 
on the access to the real estate forwards the text of this agreement to the President of the Office of Electronic Communications within 14 days from the date of its signature, and what is more, that the access agreement is public.

Regarding the conclusion of the agreement specifying the terms of access to the property, it should also be mentioned that this activity is an ordinary management activity.

\section{Proceedings regarding access to the property}

In Art. 30(5) of the Act on supporting the development of telecommunications services and networks (2010), the legislator predicted that in terms of the obligation to provide access to the property, Art. 20-24a of this Act are applied respectively. As a consequence, in the event of failure to negotiate the conclusion of an agreement on access to the property, refusal of access or failure to conclude an access agreement within 30 days since the day of submitting an application for such access, the telecommunications provider may apply to the President of the Office of Electronic Communications with a request for issuing a decision regarding access to the real estate, which, in a situation if it contains a positive decision for the entrepreneur, will replace the contract discussed above.

In this place, it can be mentioned that Adamczewski (2016) assumes that the refusal of access to the real estate should also be considered as giving the telecommunications undertaking unjustified terms of access to the property, while expressing apparent consent. Thus, it is irrelevant whether the case involved a real, explicit refusal to grant access to the real estate.

\subsection{Proceedings before the President of the Office of Electronic Communications}

The authority that is competent to issue a decision on the access to technical infrastructure is the President of the Office of Electronic Communications (hereinafter: the President of UKE) ${ }^{1}$. Proceedings before this authority are conducted on the basis of the provisions of the Code of administrative procedure (1960) with amendments resulting from the Act on supporting the development of telecommunications services and networks (2010).

Proceedings on the access to the property in order to provide telecommunications network are initiated by the President of UKE upon request. The telecommunications undertaking may apply with this kind of request. Apart from the applicant, the property manager will be a party to the proceedings, provided that the entrepreneur has previously applied to him/her for providing access to the property.

The date by which the President of UKE should finish the proceedings and issue a decision in the case is 60 days from the date of submitting the application.

${ }^{1}$ In Polish, the official abbreviation of the Office of Electronic Communications (i.e. Urząd Komunikacji Elektronicznej, UKE). 
If the matter is not resolved by the indicated date, the regulation of Art. 36(1) of the Code of administrative procedure (1960) in conjunction with Art. 206(1) of the Telecommunications law (2004) will be applied.

Before making a decision regarding access to the real estate in order to provide telecommunications, the President of UKE, except in the cases specified in the Act, conducts consultative proceedings, enabling interested parties to express their positions in the settlement in writing. Unless the President of UKE establishes a longer deadline, the consultation procedure lasts 30 days from the date of announcing the commencement of this proceeding. Information on ongoing consultations, including draft decisions, is published by the President of UKE in the UKE Public Information Bulletin.

At the stage of consultative proceedings, the property manager should therefore read in detail the draft decision in the case and submit any comments to the project.

Then, before the administrative decision is finally issued, the manager also has an opportunity to get acquainted with the case files and termination of the collected evidence and materials.

What is also important, according to Art. 206(2aa) of the Telecommunications law (2004), the decision of the President of UKE regarding access to the real estate is immediately enforceable.

\subsection{Appeal proceedings}

The parties have the right to appeal against the proposed resolution. However, in the proceedings regarding access to the property in order to ensure telecommunications, the legislator provided, in this respect, for a significant difference. As a rule, the decision of the public administration body can be appealed to the higher-level authority within the administrative course of the instance or, alternatively, the application for reconsideration of the matter to the body that issued the decision may also be made. In accordance with Art. 206(2) point 6 of the Telecommunications law (2004), from the decisions referred to, among others in Art. 30(5) of the Act on supporting the development of telecommunications services and networks (2010), you are allowed to appeal to the District Court in Warsaw - the Court of Competition and Consumer Protection. As a result, the appeal procedure will be based on the provisions of the Code of civil procedure (1964) and not on the regulation of the Code of administrative procedure (1960).

The doctrine notes that the content of the appeal is partly similar to the elements that make up the claim in civil procedure, however, with a reservation that the application contained in the appeal will come down to the demand to revoke or change the contested decision in whole or in part (Krześ, 2019). The appeal should therefore satisfy the requirements provided for the pleading, specified in particular in Art. 126 of the Code of civil procedure (1964) and should include the designation of the contested decision, citation of charges, their brief justification, indication of evidence, as well as, as already mentioned above, should 
include an application to repeal or change the decision in whole or in part (Code of civil procedure, 1964, Art. $\left.479^{60}\right)$. It is also important to specify in the appeal the value of the subject of dispute. Lack in this respect and failure to supplement it within the deadline set by the Court is the basis for rejecting the appeal (Flaga-Gieruszyńska, 2017).

The appeal against the decision of the President of UKE regarding access to the real estate is lodged with the Court of Competition and Consumer Protection, however, through the President of UKE within two weeks from the date of delivery of the decision (Code of civil procedure, 1964, Art. $479^{58} \$ 1$ ). At the same time, it is the so-called procedural time-limit and, therefore, it can be restored on general terms (Krześ, 2019).

In connection with the filed appeal, the President of UKE is entitled to revoke or change his/her decision in whole or in part when he/she considers the lodged appeal to be justified. In this case, the authority does not forward the files to the court, and they immediately inform the party about the repeal or change of the decision by sending them the new decision. The party has the right to file an appeal against the new decision (Code of civil procedure, 1964, Art. $479^{59}$ $\$ 2)$.

On the other hand, if the President of UKE does not share the appealing position, he/she should immediately forward the appeal together with the case files to the Court of Competition and Consumer Protection (Code of civil procedure, 1964, Art. $479^{59} \$ 1$ ). It should also be noted that the Supreme Administrative Court pointed out that 'the transmission by the President of the Office of Electronic Communications of the appeal against his/her decision to the Court of Competition and Consumer Protection (...) is not an act referred to in Art. 3 $\$ 2$ point 4 of the Act of 30 September 2002: the law on proceedings before administrative courts (...), whose non-execution gives the appealing party the right to complain to the administrative court for inactivity specified in Art. $3 \$ 2$ point 8 of this Act' (Resolution, 2010).

In a situation where the Court of Competition and Consumer Protection finds that the appeal was filed after the deadline for its submission, it is unacceptable for other reasons or if its deficiencies were not completed within the prescribed period - the appeal will be rejected, in accordance with Art. $479^{58} \$ 2$ of the Code of civil procedure (1964). The decision in this respect may be appealed to the court of appeals (Krześ, 2019). If the appeal is admissible, has been filed in due time and is not burdened by formal defects or these deficiencies have been supplemented, the Court will take measures aimed at substantive settlement of the appeal.

In this place, it should be pointed out again that the decision regarding access to the property is immediately enforceable, pursuant to Art. 206(2aa) of the Telecommunications law (2004). Thus, filing the appeal by the administrator does not suspend its execution, and as a consequence, the administrator is obliged to undertake the duties imposed on him/her in the decision. However, by lodging the appeal, the administrator may at the same time request the Court to sus- 
pend the implementation of that decision pending the outcome of the case. Such an application should be justified by the circumstance of the occurring danger of causing significant damage or causing irreversible consequences. A decision on the suspension of the execution of the decision may be issued at a closed session (Code of civil procedure, 1964, Art. $479^{63}$ ), and thus without the participation of the administrator.

With regard to substantive decisions that can be issued by the Court of Competition and Consumer Protection in the proceedings pending as a result of the appeal against the administrative decision regarding access to the real estate, it should be indicated that the court is entitled to dismiss the appeal or consider it. If the appeal is upheld, the court either repeals or changes in whole or in part the contested decision and decides on the merit of the case (Code of civil procedure, 1964, Art. $479^{75} \$ 1$ and 2). It is noted that the Court of Competition and Consumer Protection, deciding in the matter as a result of an appeal against the decision of the President of UKE, should make a proper assessment of the legitimacy of the appeal filed, and not rely solely on reviewing the legality of the administrative proceedings pending before (Cudak, 2016). The decision should be revoked, for example, in a situation when there was an unjustified omission of the consultative proceedings by the President of UKE during the administrative procedure (Judgment of the Supreme Court, 2012) Also, it needs to be mentioned that the Court of Appeals in Warsaw indicated that the judgment issued by the Court of Competition and Consumer Protection is not a cassation appeal in relation to administrative decisions. Therefore, the annulment of the decision of the President of UKE is effective ex tunc (Krześ, 2019; Judgment of the Court of Appeals, 2012).

The court may also issue a decision in which the proceedings are discontinued, in particular if the appeal is withdrawn by the applicant.

With regard to the procedural rights of the administrator during the appeal proceedings, it should also be pointed out that if the court issues a substantive verdict, the administrator is entitled to appeal to the Court of Appeals in Warsaw through the court that issued the decision in the first instance. Thus, proceedings before a common court are two-instance proceedings.

On the other hand, the administrator is entitled to a cassation appeal to the Supreme Court against the judgment of the Court of Appeals in Warsaw.

\section{Statitical data}

In connection with the preparation of this article, the President of UKE has been requested to provide public information in accordance with the Act on the access to public information (2001). The requested information included data on the number of proceedings initiated by the President of UKE pursuant to Art. 20(1) in connection with Art. 30(5) of the Act on supporting the development of telecommunications services and networks (2010) respectively in the years 2015-2017. 
As a result of the recognition of this request, the President of UKE shared the information 'concerning the number of administrative proceedings conducted by the President of UKE in 2015-2017 regarding access to the infrastructure and real estate pursuant to Art. 30 of the Mega-Act'. The statistical data resulting from the provided information are presented in the chart 1 and chart 2.

The obtained data show that in 2015 the President of UKE initiated 80 proceedings regarding access to infrastructure or property in order to provide telecommunications. In 2016, the number of initiated proceedings amounted to 127. However, in 2017, 297 proceedings were initiated in this matter. Therefore, the number of initiated proceedings in the analyzed period increased significantly and in 2017 was nearly four times higher than in 2015. The total number of proceedings initiated in the period 2015-2017 was 504 (chart 1).

Chart 2 illustrates statistical data regarding the number of administrative decisions on the access to the real estate in order to provide telecommunications that were issued by the President of UKE in the years 2015-2017.

Similarly to the number of initiated proceedings, the number of decisions issued in the analyzed period also increased. In 2015, the President of UKE issued 45 decisions on this matter, in 2016 - 69 decisions, whereas in 2017 - 87 decisions. On the other hand, the total number of decisions issued in 2015-2017 amounted to 201.

According to the data obtained from the President of UKE, in recent years, the scope of using the power vested in the telecommunications undertakings on the basis of the regulation discussed in this article has increased. It is also necessary to bear in mind that the administrative decision issued by the President of UKE may include a greater number of properties at the same time.

\section{Conclusion}

Providing the public with wide and easy access to telecommunications networks and services offered through them is currently essential. It affects in particular broad public access to various types of information and communication. Property managers should therefore fulfill their obligations in the field of cooperation with telecommunications companies, aiming to provide them with the real estate. Failure to comply with these obligations may lead to the initiation of an appropriate procedure, which may result in ordering the administrator to provide the property to a given entity.

The introduction of legal regulation enabling the public administration body to adopt an imperious resolution of the case of access to the property in order to provide telecommunications, an example of which is the regulation of Art. 21(2) in conjunction with Art. 30(5) of the Act on supporting the development of telecommunications services and networks (2010), seems to be fully justified.

In this place, however, it should be pointed out that this regulation should take into account both the interests of telecommunications companies and property managers, and thus their owners and perpetual usufruct users. The adjudi- 
cation of the public administration body has direct effects in the sphere of rights in rem of specific parties to the proceedings.

Consequently, the solutions adopted in the legal regulation discussed herein should be considered justified. In particular, the need to conduct a consultation procedure, in which the interested party (particularly the property manager) is entitled to express his/her position in writing in relation to the draft decision of the President of UKE, deserves to be approved. The current regulation that provides for consideration of the appeal against the decision of the President of UKE by a common court in two-instance civil proceedings also deserves a positive opinion. This court has the opportunity to hear the case and decide on the merits of the case.

\section{References}

Adamczewski, P. (2016). Stosowanie prawa konkurencji na rynkach regulowanych: udział państwa w gospodarce a ochrona konkurencji. In T. Skoczny (Ed.), Prawo konkurencji 25 lat: Pierwszy Polski Kongres Prawa Konkurencji. Warszawa: Wolters Kluwer.

Babis, H. (2011). Istota rynku ustug telekomunikacyjnych. In H. Babis, \& K. Flaga-Gieruszyńska (Eds.), Rynek ustug telekomunikacyjnych. Warszawa: Lex a Wolters Kluwer business.

Cudak, A. (2016). Komentarz do art. $479^{75}$ Kodeksu postępowania cywilnego. In A. Marciniak, \& K. Piasecki (Eds.), Kodeks postępowania cywilnego: komentarz. Warszawa: C.H. Beck.

Flaga-Gieruszyńska, K. (2017). Postępowanie w sprawach o naruszenie posiadania. In A. Zieliński (Ed.), Kodeks postępowania cywilnego: komentarz. Warszawa: C.H. Beck.

Judgment of the Court of Appeals in Warsaw of 26 April 2012 (VI ACa 1385/11). Judgment of the Supreme Court: Chamber of Labor, Social Security and Public Affairs of 18 May 2012 (III SK 37/11).

Knopkiewicz, W. (2013). Komentarz do art. 30 Ustawy o wspieraniu rozwoju usług i sieci telekomunikacyjnych. In T. Grossmann, W. Knopkiewicz, J. Sebzda-Załuska, M. Szydło, \& J. Wilczewski (Eds.), Ustawa o wspieraniu rozwoju ustug i sieci telekomunikacyjnych: komentarz. Warszawa: C.H. Beck.

Krześ, S. (2019). Komentarz do art $479^{58}$ Kodeksu postępowania cywilnego. In E. Marszałkowska-Krześ (Ed.), Kodeks postępowania cywilnego: komentarz. Warszawa: Beck Online.

Resolution of the Composition of the Seven Judges of the Supreme Administrative Court of 23 February 2010 (II GPS 6/09).

UKE. (2013). Stanowisko prezesa Urzędu Komunikacji Elektronicznej w sprawie stosowania art. 30 Ustawy o wspieraniu rozwoju ustug i sieci telekomunikacyjnych. Retrieved 11.02.2018 from https://archiwum.uke.gov.pl. 
Ustawa z dnia 14 czerwca 1960 r. Kodeks postępowania administracyjnego [Act of 14 June 1960 Code of administrative procedure] (Dz.U. $1960 \mathrm{nr} 30$ poz. 168) (Poland).

Ustawa z dnia 16 lipca 2004 r. Prawo telekomunikacyjne [Act of 16 July 2004 Telecommunications law] (Dz.U. 2004 nr 171 poz. 1800) (Poland).

Ustawa z dnia 17 listopada $1964 \mathrm{r}$. Kodeks postępowania cywilnego [Act of 17 November 1964 Code of civil procedure] (Dz.U. 1964 nr 43 poz. 296) (Poland).

Ustawa z dnia 6 września 2001 r. o dostępie do informacji publicznej [Act of 6 September 2001 on the access to public information] (Dz.U. $2001 \mathrm{nr} 112$ poz. 1198) (Poland).

Ustawa z dnia 7 maja 2010 r. o wspieraniu rozwoju usług i sieci telekomunikacyjnych [Act of 7 May 2010 on supporting the development of telecommunications services and networks] (Dz.U. $2010 \mathrm{nr} 106$ poz. 675) (Poland).

Windekilde, I., \& Ładny, P. (2011). Sieci telekomunikacyjne. In H. Babis, \& K. Flaga-Gieruszyńska (Eds.), Rynek ustug telekomunikacyjnych. Warszawa: Lex a Wolters Kluwer business.

\section{Acknowledgements}

Author contributions: authors have given an approval to the final version of the article. Authors contributed to this work as follows: M.D. and P.C. developed the concept and designed the study, P.C. collected the data, M.D. and P.C. analysed and interpreted the data, M.D. and P.C. prepared draft of article, M.D. and P.C. revised the article critically for important intellectual content.

Funding: this research was funded by the authors' own resources.

Supplementary information: authors acknowledge following institution for help with the preparation of the article: Office of Electronic Communications. 


\section{Appendix}

\section{Chart 1.}

Number of administrative proceedings regarding access to the infrastructure or real estate in order to provide telecommunications initiated in 2015-2017

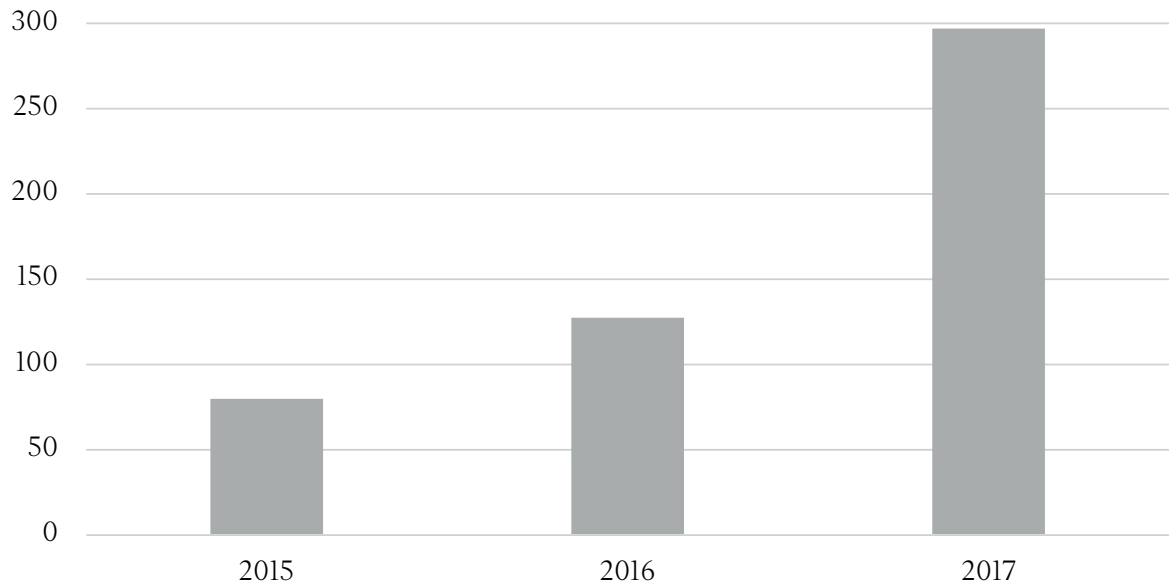

Source: Own preparation based on the data from the President of UKE.

\section{Chart 2.}

Number of administrative decisions regarding access to the real estate to provide telecommunications issued by the President of UKE in 2015-2017

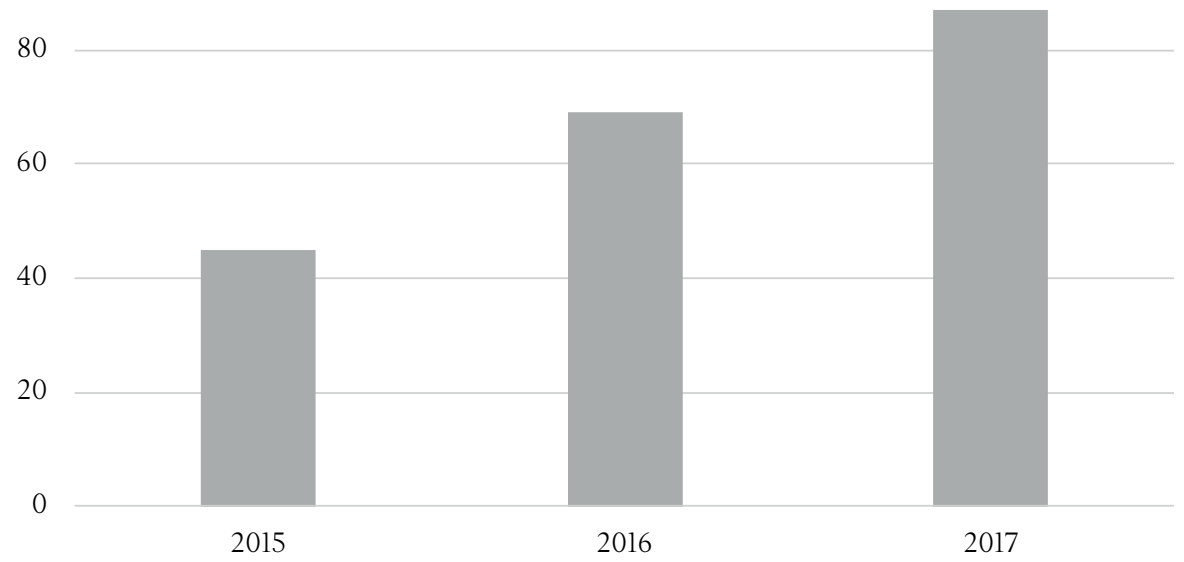

Source: Own preparation based on the data from the President of UKE. 